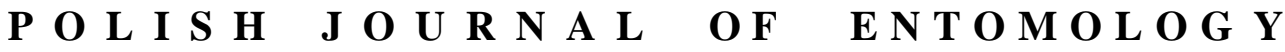

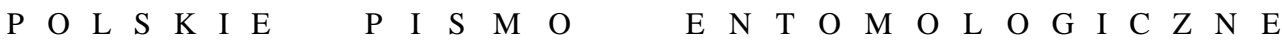

VOL. 83: $313-323$

Lublin

31 December 2014

DOI: $10.2478 /$ pjen-2014-0024

\section{Participation of some protein fractions in interactions between Acrobasis advenella (ZINCKEN, 1818) (Lepidoptera, Pyralidae) and its host plants}

\author{
EDYTA GÓRSKA-DRABIK
}

Department of Entomology, University of Life Sciences in Lublin, Leszczyńskiego 7, 20-069 Lublin, Poland, e-mail: edyta.drabik@up.lublin.pl

\begin{abstract}
The present study determined the impact of Acrobasis advenella caterpillars feeding on the content of total proteins, specific proteins and soluble proteins in the inflorescences of three host plant species: Aronia melanocarpa, Sorbus aucuparia and Crataegus monogyna. The study demonstrated that the feeding of A. advenella caterpillars increases the total, specific and soluble protein contents in the inflorescences of these three plants. Significant increases in the content of these compounds were observed in the infested inflorescences of black chokeberry.
\end{abstract}

KEY WORDS: Acrobasis advenella, proteins, plant-insect interactions, Aronia melanocarpa, Sorbus aucuparia, Crataegus monogyna.

\section{INTRODUCTION}

Many recent studies of plant-herbivore interactions indicate that these are very complex, if only because of the huge number of insects and host plants. Therefore, specific plant species may react in different ways to tissue damage caused by different insect species. Plant-herbivore interactions may also depend on about 200000 metabolites that have so far been isolated from plants. There are about 15000 metabolites in the tissues of a single plant species (FERNIE 2007). The chemical composition of plants changes as diverse groups of herbivores forage on them; it is also affected by other biotic and abiotic factors (PANDA \& KHUSH 1995, STOWE 1998). 
Plants have developed different defence mechanisms against attacks from phytophagous insects by activating metabolic pathways that change their chemical properties. They produce biomolecules, mainly secondary metabolites and defensive proteins, that can set up resistance to pests (BALDWIN 2001, FORDYCE \& AGRAWAL 2001, HARUTA et al. 2001). Among primary metabolites, proteins, besides sugars, play an important role in interactions between herbivorous insects and their hosts (DĄBROWSKI 1988, GIROUSSE \& Bournoville 1994, Karban \& Baldwin 1997, SEMPRUCH \& Ciepiela 1999, 2002, KiEtKIEWICZ-SzANiawsKa 2003, MALINOWSKI 2008, SEMPRUCH 2010). The protein contents in host plant tissues are thought to be an indicator of food quality, as they are the main source of amino acids for herbivores, thus governing the latter's growth and development (SEMPRUCH \& CiEPIELA 2002, BABIC et al. 2008, MALINOWSKI 2008). The consumption of protein by larvae may determine the further development of an insect, both in the pupal and adult stages (mainly during egg production) (CHAN et al. 1990). Modern analytical techniques permit a much better understanding of the part played by particular compounds in interactions between plants and herbivores. Current knowledge indicates that primary metabolites do not only determine food quality but may also function as a component of signalling defence pathways (KIEŁKIEWICZ et al. 2010a). The best known elements of plant defences against herbivores are the group of jasmonic acid-regulated proteins, which play the main role in plant defence by targeting the insect digestive canal to impair its digestive and absorptive processes (FELTON 2005, KIEEKIEWICZ et al. 2010b). The proteins also function as precursors of secondary metabolites, which are the main elements of resistance in plants (HASLAM \& LILLEY 1985). A high participate of proteins so far identified is predicted to be involved in stress and defence reactions, but their exact physiological functions remain to be established.

Acrobasis advenella (ZINCKEN, 1818) commonly occurs in Europe, and its caterpillars feed mainly on plants of the genera Crataegus LINNAEUS, 1753, Sorbus LINNAEUS, 1753 and Prunus Linnaeus, 1753 (Goater 1986, PaLm 1986, Slamka 1997). The presence of this species on Aronia melanocarpa in Poland was first recorded in 2004 (GÓRSKA-DRABIK 2009). Further studies in later years established their presence on black chokeberry plantations all over Poland (GóRSKA-DRABIK 2013).

The literature data indicate that a plant's reaction to biotic stress caused by insects depends not only on the phytophagous species, but also on the plant species. In this context, the present paper discusses the effect of A. advenella caterpillars feeding on the total protein, specific protein and soluble protein contents in tissues of three host plant species. 


\section{MATERIAL AND METHODS}

\section{Field studies}

The test material consisted of inflorescences of black chokeberry (Aronia melanocarpa [MiCHAUX, 1803] ElLIOT, 1821), rowan (Sorbus aucuparia LINNAEUS, 1753) and singleseeded hawthorn (Crataegus monogyna LiNNAEUS, 1753), both colonised and not colonised by caterpillars of $A$. advenella. It was collected on the black chokeberry plantation at Boduszyn (15 km from Lublin), where branches are pruned and fertiliser is applied every few years. The inflorescences of rowan and hawthorn were collected from small groups of trees (not fertilised) growing in green areas of Lublin. Inflorescences were collected when caterpillars started feeding, i.e. in the last 10 days of April 2011 and 2012. The feeding caterpillars were removed from the inflorescences. Next, both infested and uninfested inflorescences were dried at temperatures up to $35^{\circ} \mathrm{C}$.

\section{Biochemical analysis}

The chemical analyses were performed on dry material (DW) in three replicates each year. The total and specific protein contents were determined using Kjeldahl's method with the Kjeltec system 1030, after prior mineralisation in a DS-20 block (WIERCIŃSKI 1999). The soluble proteins were calculated as the difference between the amount of specific and total proteins. The content and changes in concentration of proteins in the control and infested inflorescences are given as a percentage of the dry weight (\% of DW). The analyses were done at the Central Laboratory of Agroecology of the University of Life Sciences, Lublin (according to CLA/PSO/13 version 3), and at the Laboratory of the Department of Vegetable Crops and Medicinal Plants of the University of Life Sciences, Lublin.

\section{Statistical analysis}

The differences between the means for the variables were determined from analysis of variance (ANOVA), assuming normality of distribution and homogeneity of variance.

The significance of the difference between the means was tested using Tukey's Honestly Significant Difference test $(H S D)$ at a significance level of $\mathrm{P}=0.05$. The $\mathrm{F}$ statistics value of the variables is presented in the table and the figures with the results. The values of the means $(\bar{X})$ in the tables are given with standard errors $( \pm \mathrm{SE})$. The values on the figures are shown as the arithmetic average of 2011 and 2012 values. The statistical analysis was performed using Statistica 9.1 (StatSoft, Tulsa). 


\section{RESULTS}

The statistical analysis confirmed that in 2011 and 2012 there were no significant differences in the total protein content in the control inflorescences of the plant species (black chokeberry $-\mathrm{F}_{(1,4)}=0.003 \mathrm{p}=0.95861$; rowan $-\mathrm{F}_{(1,4)}=3.810 \mathrm{p}=0.12264$ and hawthorn $\left.-\mathrm{F}_{(1,4)}=6.000 \mathrm{p}=0.06972\right)$. The content of specific proteins in the control inflorescences of all the plant species in 2012 was significantly higher in comparison to 2011 (black chokeberry $-\mathrm{F}_{(1,4)}=23.310 \mathrm{p}=0.008476$; rowan $-\mathrm{F}_{(1,4)}=496.890 \mathrm{p}=$ 0.00002 and hawthorn $\left.-F_{(1,4)}=25.620 \mathrm{p}=0.00700\right)$.

Table 1. The content of total protein, specific protein and soluble protein (\% of DW) in infested inflorescences of Acrobasis advenella host plant species $(2011,2012)$.

\begin{tabular}{|l|c|c|c|c|c|c|}
\hline \multirow{2}{*}{ Host plant species } & \multicolumn{2}{|c|}{ Total protein } & \multicolumn{2}{c|}{$\begin{array}{c}\text { Specific protein } \\
\text { X } \pm \text { SE }\end{array}$} & \multicolumn{2}{c|}{$\begin{array}{c}\text { Soluble protein } \\
\text { X } \pm \text { SE }\end{array}$} \\
\cline { 2 - 7 } & $\mathbf{2 0 1 1}$ & $\mathbf{2 0 1 2}$ & $\mathbf{2 0 1 1}$ & $\mathbf{2 0 1 2}$ & $\mathbf{2 0 1 1}$ & $\mathbf{2 0 1 2}$ \\
\hline \multirow{2}{*}{ Black chokeberry } & $21.50 \mathrm{a}$ & $18.93 \mathrm{ab}$ & $0.80 \mathrm{~b}$ & $0.98 \mathrm{a}$ & $20.70 \mathrm{a}$ & $25.52 \mathrm{a}$ \\
& \pm 2.99 & \pm 2.19 & \pm 0.001 & \pm 0.103 & \pm 2.99 & \pm 1.19 \\
\hline Rowan & $22.74 \mathrm{a}$ & $22.59 \mathrm{~b}$ & $0.89 \mathrm{a}$ & $1.01 \mathrm{a}$ & $21.85 \mathrm{a}$ & $22.49 \mathrm{~b}$ \\
& \pm 0.12 & \pm 0.71 & \pm 0.011 & \pm 0.013 & \pm 0.13 & \pm 0.12 \\
\hline Single-seeded hawthorn & $27.20 \mathrm{a}$ & $28.33 \mathrm{a}$ & $0.54 \mathrm{c}$ & $0.62 \mathrm{~b}$ & $26.66 \mathrm{a}$ & $27.71 \mathrm{a}$ \\
& \pm 0.21 & \pm 0.18 & \pm 0.006 & \pm 0.097 & \pm 0.21 & \pm 0.12 \\
\hline $\mathrm{F}_{(2,6)}$ & 3.0 & 12.2 & 649.0 & 7.1 & 3.3 & 14.3 \\
$\mathrm{P}$ & 0.12 & 0.008 & $1 \cdot 10^{-14}$ & 0.03 & 0.11 & 0.01 \\
\hline
\end{tabular}

The values in the same columns followed by various letters are significantly different at $\mathrm{P} \leq 0.05$ (Tukey's HSD test).

Table 2. The content of total protein, specific protein and soluble protein (\% of DW) in control inflorescences of Acrobasis advenella host plant species $(2011,2012)$.

\begin{tabular}{|l|c|c|c|c|c|c|}
\hline \multirow{2}{*}{ Host plant species } & \multicolumn{2}{|c|}{$\begin{array}{c}\text { Total protein } \\
\mathbf{X} \pm \mathbf{S E}\end{array}$} & \multicolumn{2}{c|}{$\begin{array}{c}\text { Specific protein } \\
\mathbf{X} \pm \text { SE }\end{array}$} & \multicolumn{2}{c|}{$\begin{array}{c}\text { Soluble protein } \\
\mathrm{X} \pm \text { SE }\end{array}$} \\
\cline { 2 - 7 } & $\mathbf{2 0 1 1}$ & $\mathbf{2 0 1 2}$ & $\mathbf{2 0 1 1}$ & $\mathbf{2 0 1 2}$ & $\mathbf{2 0 1 1}$ & $\mathbf{2 0 1 2}$ \\
\hline Black chokeberry & $18.80 \mathrm{c}$ & $26.50 \mathrm{~b}$ & $0.61 \mathrm{~b}$ & $0.66 \mathrm{~b}$ & $18.19 \mathrm{c}$ & $18.27 \mathrm{~b}$ \\
& \pm 1.02 & \pm 1.19 & \pm 0.008 & \pm 0.009 & \pm 1.01 & \pm 2.19 \\
\hline Rowan & $21.96 \mathrm{~b}$ & $23.50 \mathrm{~b}$ & $0.87 \mathrm{a}$ & $0.94 \mathrm{a}$ & $21.09 \mathrm{~b}$ & $21.65 \mathrm{ab}$ \\
& \pm 0.25 & \pm 0.11 & \pm 0.0003 & \pm 0.003 & \pm 0.11 & \pm 0.31 \\
\hline Single-seeded hawthorn & $25.87 \mathrm{a}$ & $26.23 \mathrm{a}$ & $0.48 \mathrm{c}$ & $0.60 \mathrm{~b}$ & $25.39 \mathrm{a}$ & $25.63 \mathrm{a}$ \\
& \pm 0.12 & \pm 0.09 & \pm 0.0003 & \pm 0.024 & \pm 0.12 & \pm 0.09 \\
\hline $\mathrm{F}_{(2,6)}$ & 33.6 & 7.5 & 2051.4 & 148.2 & 37.4 & 8.3 \\
$\mathrm{P}$ & 0.0006 & 0.02 & $1 \cdot 10^{-14}$ & 0.000008 & 0.0004 & 0.02 \\
\hline
\end{tabular}

The values in the same columns followed by various letters are significantly different at $\mathrm{P} \leq 0.05$ (Tukey's HSD test). 


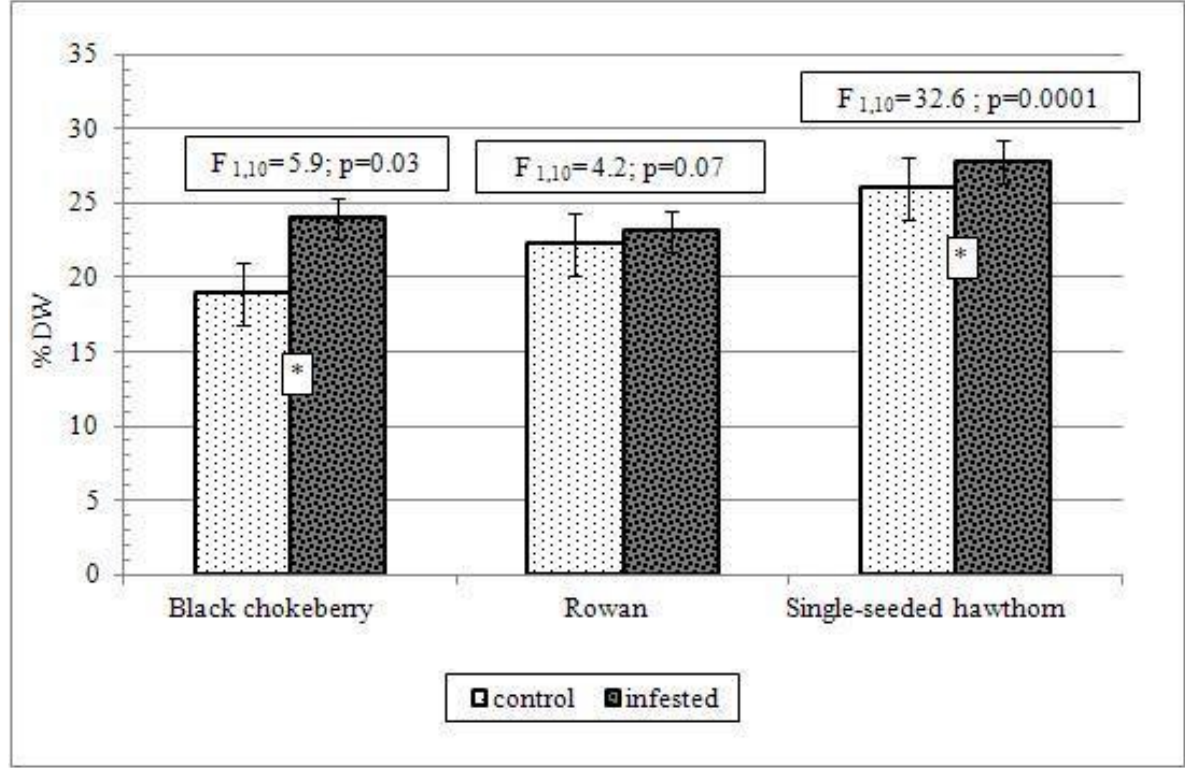

Fig. 1. Changes in total protein content (\% of DW) in infested inflorescences of Acrobasis advenella host plant species (average 2011-2012). Values marked * are significantly different at $\mathrm{P} \leq 0.05$ (Tukey's HSD test).

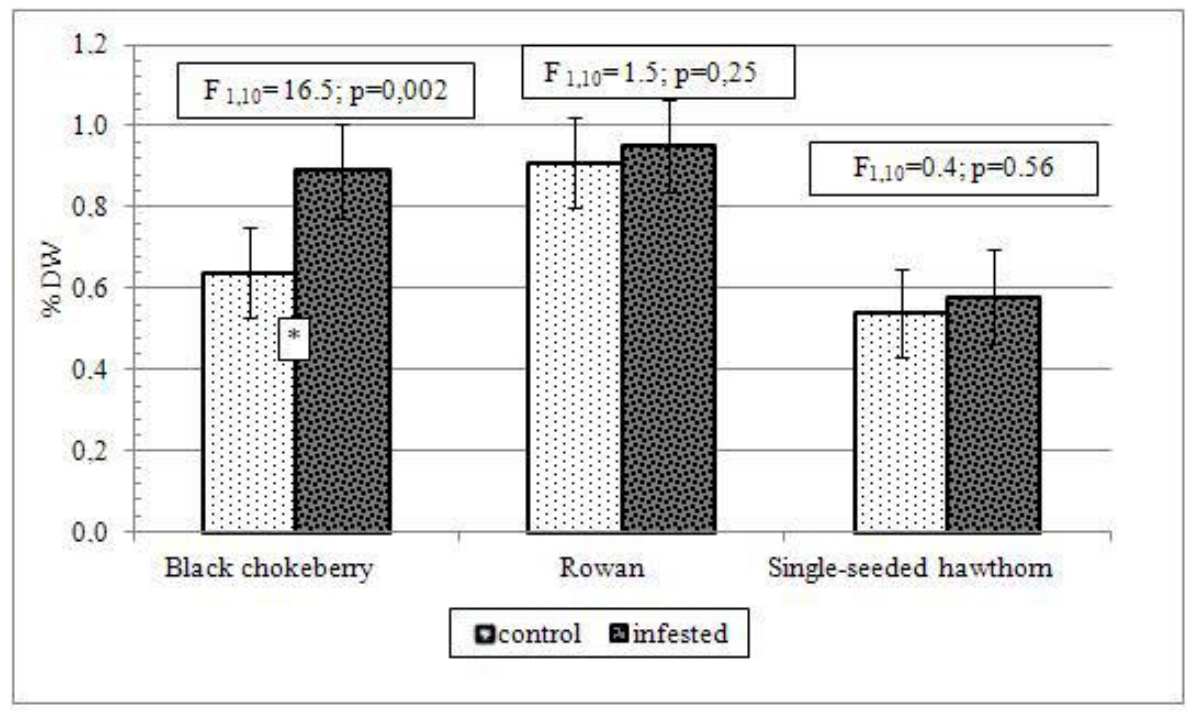

Fig. 2. Changes in specific protein content (\% of DW) in infested inflorescences of Acrobasis advenella host plant species (average 2011-2012). Values marked * are significantly different at $\mathrm{P} \leq 0.05$ (Tukey's HSD test). 


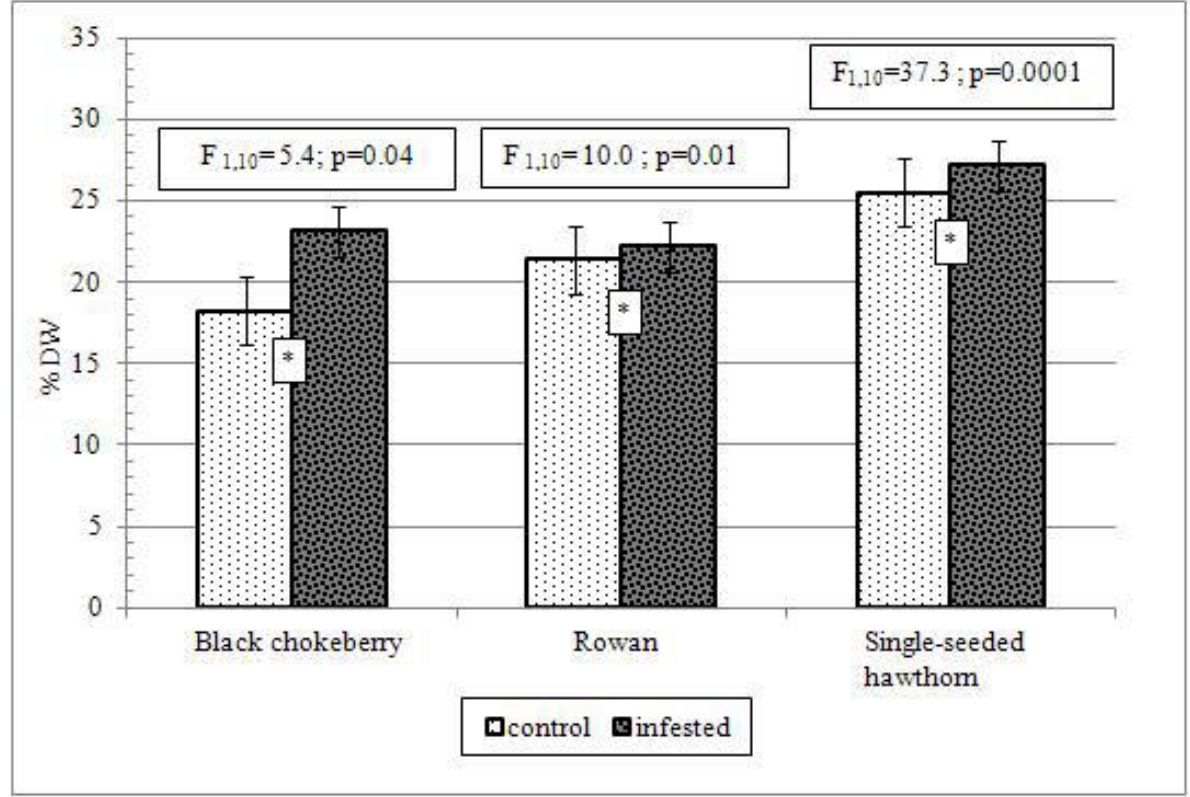

Fig. 3. Changes in soluble protein content (\% of DW) in infested inflorescences of Acrobasis advenella host plant species (average 2011-2012). Values marked * are significantly different at $\mathrm{P} \leq 0.05$ (Tukey's HSD test).

The total protein contents in the infested inflorescences ranged from $18.93 \%$ (black chokeberry) to $28.33 \%$ of DW (hawthorn) (Table 1). The statistical analysis confirmed the significantly higher contents of these compounds in C. monogyna tissues only in 2012. The specific protein contents in the inflorescences ranged from $0.54 \%$ (hawthorn) to $1.01 \%$ of DW (rowan). There were significant differences between the contents of this compound in extracts from hawthorn and from the other plants. The soluble protein content ranged from $20.70 \%$ (black chokeberry) to $27.71 \%$ of DW (hawthorn). The statistical analysis did not confirm any significant differences in the contents of these compounds between the three plant species in 2011. The total protein contents in the tissues of the control plants varied from $18.80 \%$ (black chokeberry) to $26.50 \%$ of DW (black chokeberry) (Table 2). In both study years there were significant differences in the total protein contents in the tissues of these plants. The specific protein content in uninfested inflorescences ranged between $0.48 \%$ (hawthorn) and $0.94 \%$ of DW (rowan). It was significantly higher in rowan inflorescences than in the other plants in both years. The soluble protein content in the tissues of the control plants ranged from $18.19 \%$ (black chokeberry) to $25.63 \%$ of DW (hawthorn). The inflorescences of all the infested plant species contained more total, 
specific and soluble proteins than the control material (Figs 1-3). The total protein content in black chokeberry and hawthorn inflorescences was significantly higher than in the control. The greatest increase in these compounds (by $21 \%$ ) was noted in the inflorescences of black chokeberry, whereas the respective increases in hawthorn and rowan tissues were over $6 \%$ and almost $4 \%$ in comparison to the control (Fig. 1). There was a significant increase in the specific protein content (over 28\%) in infested inflorescences of black chokeberry compared to the control (Fig. 2). In the other two plant species, the increase in the specific protein content was 7\% (hawthorn) and 4\% (rowan), but no significant differences were found. The concentration of soluble proteins in the inflorescences of all the plant species colonised by caterpillars was significantly higher than in the control plants. The inflorescences of black chokeberry contained $21 \%$ more of these compounds, and those of rowan and hawthorn $4 \%$ and $6 \%$ more respectively (Fig. 3).

\section{DISCUSSION}

Proteins can play diverse roles in plants and phytophagous interactions. They are the main source of nutrients for herbivores, especially amino acids, which are necessary for their proper growth and development, and they also participate in plant defence mechanisms against phytophagous insects (SEMPRUCH \& CIEPIELA 2002, BABIC et al. 2008).

The protein contents of specific plant tissues differ and can determine their attractiveness for herbivores. Plants that are nutritionally unattractive to herbivores contain only small amounts of primary metabolites, mainly proteins (DĄBROWSKI 1988). According to KIEŁKIEWICZ-SZANIAWSKA (2003) cultivars of tomatoes with low soluble protein contents are not very attractive to the carmine spider mite (Tetranychus cinnabarinus BOISDUVAL, 1867), whereas cultivars heavily colonised by pests contained more of these compounds. GANTNER (2007) showed that the hazel cultivar most susceptible to the feeding of Myzocallis coryli GOETZE, 1778 and Phytoptus avellanae NALEPA, 1889 contained large amounts of primary metabolites, i.e. proteins and sugars. In the present study the total protein and soluble protein contents were the highest in the inflorescences of hawthorn and the lowest in those of black chokeberry.

The reactions of plants to harmful biotic factors, such as the attack of herbivores, involve metabolic changes, the nature of which depends to a great degree on the attacking organisms (BRUCE \& PICKET 2007). Plants usually react to insects by decreasing the nutrient content of their tissues (MALINOWSKI 2008). There is no information in the available literature relating to the influence of $A$. advenella caterpillars feeding on the protein contents in host plant tissues. 
The results showed that phytophage-damaged inflorescences of black chokeberry and hawthorn contained significantly more total proteins. The soluble protein content was significantly higher in the tissues of all three plants. The results are consistent with the report by GANTNER (2007), while from the research of KIEŁKIEWICZ-SZANIAWSKA (2003) it appears that in the initial stage of red spider mites feeding on tomatoes, the soluble protein content decreased in the tissues of damaged plants, whereas a slight increase was noted two weeks later. In this study, the highest increase in the soluble protein content was noted in tissues of A. melanocarpa. This could be evidence for the more effective synthesis of defensive proteins in this species. The significance of defensive compounds in soluble proteins has been highlighted by many authors. So-called PR proteins are of special significance in such reactions as systemic acquired resistance and systemic induced resistance (ZŁOTEK \& WÓJCIK 2007). An important part is played by enzymes catalysing the biosynthesis of plant allomones and toxins, as well as proteins disrupting plant food digestion, i.e. protease and lectin inhibitors (KUSANO et al. 2007, BURGES et al. 2008, HEIL 2009, Sprawka 2008, Sempruch 2009, Zavala et al. 2009). Finally, the action of proteinase inhibitors leads to a deficiency of amino acids. This affects insect growth and development, ultimately causing death as a result of the inhibition of proteinase secretion in the gut or of the huge overproduction of digestive enzymes, which reduce the availability of essential amino acids for the production of other proteins (POMPERMAYER et al. 2001).

\section{CONCLUSIONS}

The feeding of A. advenella caterpillars causes an increase in the total, specific and soluble protein contents in black chokeberry, rowan and single-seeded hawthorn inflorescences. There were significant increases in the contents of these compounds in the infested inflorescences of black chokeberry. This could be evidence for a more effective synthesis of defensive proteins in this plant species.

\section{ACKNOWLEDGEMENTS}

The study was financed from the funds of the Ministry of Science and Higher Education in 2010-2013 as research project ( N N 310308439). 


\section{REFERENCES}

Babic B., Poisson A., Darwish S., Lacasse J., MerkX-Jacques M., Despland E., Bede J.C. 2008. Influence of dietary nutritional composition on caterpillar salivary enzyme activity. Journal of Insect Physiology 54(1): 286-296.

BALDWIN I.T. 2001. An ecologically motivated analysis of plant-herbivore interactions in native tobacco. Plant Physiology 127(4): 1449-1458.

BRuce T.J.A., Picket J.A. 2007. Plant defense signaling induced by biotic attacks. Current Opinion in Plant Biology 10(4): 387-392.

Burges E.P.J., Philip B.A., Christeler J.T., Page N.E.M., Marshall R.K., Wohlers M.W. 2008. Tri-tropic effects of transgenic insect-resistant tobacco expressing a protease inhibitor or biotinbinding protein on adults of the predatory carabid beetle Ctenognathus novaezelandiae. Journal of Insect Physiology 54(2): 518-528.

Chan H.T., HANSEN J.D., TAM S.Y.T. 1990. Larval diets from different protein sources for Mediterranean fruit flies (Diptera: Tephritidae). Journal of Economic Entomology 83(5): 1954-1958.

DĄBROwSKI Z. 1988. Plant resistance to insects: a basics approach. Państwowe Wydawnictwo Rolnicze i Leśne, Warszawa. (in Polish)

FeLton G.W. 2005. Indigestion is a plant's best defense. Proceedings of the National Academy of Sciences of the United States of America 102(52): 18771-18772.

FERNIE A.R. 2007. The future of metabolic phytochemistry: Large numbers or metabolites, higher resolution, greater understanding. Phytochemistry 68(22-24): 2861-2880.

FordyCE J.A., AgRAwAL A.A. 2001. The role of plant trichomes and caterpillar group size on growth and defense of the pipevine swallowtail Battus philenor. Journal of Animal Ecology 70(6): 997-1005.

GANTNER M. 2007. The sources of resistance of chosen hazelnut cultivars (Corylus L.) on the filbert big bud mite (Phytoptus avallanae NAL.) and filbert aphid (Myzocallis coryli GoETZE). Rozprawy Naukowe Akademii Rolniczej w Lublinie, Lublin. (in Polish)

GiROUSSE C., BourNOviLle R. 1994. Role of phloem sap quality and exudation characteristics on performance of pea aphid grown on lucerne genotypes. Entomologia Experimentalis et Applicata 70(3): 227-235.

GoAter B. 1986. British Pyralid Moths. A Guide to their Identification. Harley Books, Colchester.

GÓRSKA-DrABIK E. 2009. Trachycera advenella (ZINCK.) (Lepidoptera, Pyralidae) - a new pest on black chokeberry (Aronia melanocarpa). Progress in Plant Protection 49(1): 531-534. (in Polish)

GóRSKA-DRABIK E. 2013. Occurrence of Acrobasis advenella (ZINCK.) (Lepidoptera, Pyralidae, Phycitinae) on black chokeberry in Poland and its biochemical interaction with host plants. Rozprawy Naukowe Uniwersytetu Przyrodniczego w Lublinie, Lublin. (in Polish)

Haruta M., Major I.T., Christopher M.E., Patton J.J., Constabel C.P. 2001. A Kunitz trypsin inhibitor gene family from trembling aspen (Populus tremuloides MichX.): cloning, functional expression, and induction by wounding and herbivory. Plant Molecular Biology 46(3): 347-359. 
Haslam E., Lilley T.H. 1985. New polyphenols from old tannins. [in:] C.F. van Sumere, P.J. LeA (eds.). The Biochemistry of Plant Phenolics. Oxford University Press (Clarendon), London - New York, 237-256.

HeIL M. 2009. Damaged-self recognition in plant herbivore defence. Trends in Plant Science 14(7): $356-363$.

KARBAN R., BALDwin I.T. 1997. Induced Responses to Herbivory. University of Chicago Press, Chicago.

KIEŁKIEWICZ-SZANIAWSKA M. 2003. Defence strategies of tomato plants (Lycopersicon esculentum MILLER) against the carmine spider mite (Tetranychus cinnabarinus BoISDUVAL, Acari: Tetranychidae) infestation. Wydawnictwo Szkoły Głównej Gospodarstwa Wiesjkiego, Warszawa. (in Polish)

Kie€kiewicz M., Godzina M., CZAPLA A. 2010a. Activation of plant defence mechanisms against pests. Progress in Plant Protection 50(2): 885-896. (in Polish)

KietKIEwicz M., Godzina M., CZApla A. 2010b. Defence-related proteins in plant defence against pests. Progress in Plant Protection 50(2): 897-901. (in Polish)

Kusano T., YAmaguchi K., BARberich T., TAKahashi Y. 2007. Advances in polyamine research in 2007. Journal of Plant Research 120(3): 345-350.

MaLinOwSKI H. 2008. Defensive mechanisms of woody plants against harmful insects. Progress in Plant Protection 48(1): 25-33. (in Polish)

Pompermayer P, Lopes AR, Terra WR, Parra JRP, Falco MC, Silva-Filho MC. 2001. Effects of soybean proteinase inhibitor on development, survival and reproductive potential of the sugarcane borer, Diatraea saccharalis. Entomologia Experimentalis et Applicata 99(1): 79-85.

Palm E. 1986. Nordeuropas Pyralider, Danmarks Dyreliv Bind 3. Fauna Bøger, København.

PANDA N., KHUSH G.S. 1995. Host plant resistance to insects. IRRI-CABI, Wallingford.

SEMPRUCH C. 2009. Participation of the amino acids in host plants-aphids interactions. Postępy Nauk Rolniczych 61(338): 89-101. (in Polish)

SEMPRUCH C., 2010. Nitrogen compounds in interactions between plants and herbivorous insects. Kosmos 59(1-2): 199-209. (in Polish)

Sempruch C., Ciepiela P. 1999. The role of nitrogen and soluble carbohydrates in the interactions between selected species of winter cereals, and grain aphid (Sitobion avenae (F.), (Homoptera: Aphididae). Annals of Agricultural Science, ser (E), Plant Protection 28: 29-35.

Sempruch C., Ciepiela. P. 2002. Changes in content and amino acids composition of protein of winter triticale selected cultivars caused by grain aphid feeding. Journal of Plant Protection Research 42(1): 37-44.

SlamKa F. 1997. Die Zünslerartigen (Pyraloidea) Mitteleuropas. František Slamka, Bratislava.

SPRAWKA I. 2008. Toxicity of phytohemagglutinin (PHA) from Phaseolus vulgaris L., to the bird cherry-oat aphid (Rhopalosiphum padi L.). Pestycydy 2008(3-4): 101-108.

Stowe K.A. 1998. Experimental evolution of resistance in Brassica rapa: Correlated response of tolerance in lines selected for glucosinolate content. Evolution 52(3): 703-712. 
WIERCIŃSKI J. 1999. Guide to the exercise of instrumental chemical analysis of food components. Wydawnictwo Akademii Rolniczej w Lublinie, Lublin. (in Polish)

Zavala J.A., Casteel C.L., NabityP. D., Berenbaum M.R., Delucia E.H. 2009. Role of cysteine proteinase inhibitors in preference of Japanese beetles (Popillia japonica) for soybean (Glycine max) leaves of different ages and grown under elevated $\mathrm{CO}_{2}$. Oecologia 161(1): 35-41.

ZŁotek U., Wóscik W. 2007. Some aspects of mechanisms of acquiring immunity in plants. Acta Scientiarum Polonorum, ser. Biotechnologia 6(2): 3-12.

Received: 15 September 2014

Accepted: 23 October 2014 